\title{
Pneumologia
}

\section{An atypical case: RT-PCR-negative, sero-positive covid-19 patient} \author{
COVID-19 Investigation Team \\ ${ }^{1}$ Department of General Medicine, St Carolus Hospital, Jakarta, Indonesia \\ ${ }^{2}$ Department of Pulmonology, St. Carolus Hospital, Jakarta, Indonesia \\ ${ }^{3}$ Department of Pulmonology and Respiratory Medicine, Universitas Indonesia, Jakarta, Indonesia \\ ${ }^{4}$ Department of Clinical Pathology, St. Carolus Hospital, Jakarta, Indonesia \\ ${ }^{5}$ Department of Radiology, St. Carolus Hospital, Jakarta, Indonesia \\ ${ }^{6}$ Department of Internal Medicine, St. Carolus Hospital, Jakarta, Indonesia \\ ${ }^{7}$ Department of Anesthesiology and Intensive Care, St. Carolus Hospital, Jakarta, Indonesia
}

William Suriady ${ }^{1}$, Andika Chandra Putra ${ }^{2,3, *}$, Wiwien Heru Wiyono ${ }^{2,3}$, Mohammad Fahmi Alatas ${ }^{2,3}$, Bettia Bermawi ${ }^{4}$ Ratna Moniqa ${ }^{5}$, Hendra Koncoro ${ }^{6}$, Laurentius Aswin Pramono ${ }^{6}$, Fransiska ${ }^{6}$, Maria Edith Sulistio ${ }^{7}$, Ramzi ${ }^{7}$, Robert Sinto ${ }^{6}$ Rachmat Hamonangan ${ }^{6}$, Adi Surya Komala ${ }^{6}$, C. Krismini Dwi Irianti ${ }^{1}$, J.B. Endrotomo Sumargono'; The St. Carolus Hospital

Abstract

English:

The novel coronavirus disease-2019 (COVID-19), caused by the severe acute respiratory syndrome-coronavirus-2 (SARSCoV-2), has become a public health emergency of international concern. The first confirmed COVID-19 case in Indonesia was announced on 2 March 2020, and later on, 11,192 confirmed cases were reported as of 3 May. The World Health Organization has stated that performing a real-time reverse transcription-polymerase chain reaction (RT-PCR) specific for SARS-CoV-2 on specimens from the upper and the lower respiratory tracts, especially nasopharyngeal and oropharyngeal swabs, is the standard diagnostic procedure for COVID-19. In Indonesia, we also use other diagnostic tests, such as rapid antibody tests specific for SARS-CoV-2. Herein, we report an atypical case of COVID-19 and describe the diagnostic process, the clinical course, with progression to severe pneumonia on Week 3 of illness and the case management. We also try to highlight the possibility of falsenegative RT-PCR tests.

Keywords

COVID-19 $\cdot$ SARS-CoV-2 $\cdot R T-P C R \cdot$ atypical case $\bullet$ sero-positive

\section{Un caz atipic: pacient COVID 19 seropozitiv, RT-PCR negativ}

Rezumat

Romanian:

COVID-19 definește o patologie infectioasă cauzată de infecția cu noua tulpină de coronavirus (SARS-CoV-2), care a devenit în scurt timp o problemă de sănătate publică cu impact internațional. Primul caz de COVID-19 din Indonezia a fost anunțat pe 2 martie 2020, iar pe data de 3 fuseseră deja confirmate 11.192 de cazuri. Până în prezent, Organizația Mondială a Sănătății a declarat că diagnosticul standard pentru COVID-19 este detectia ARN viral prin Real-Time RT-PCR (reverse-transcription polymerase chain reaction). Se recoltează probele de la nivelul căilor respiratorii superioare și inferioare, cel mai des folosite fiind exudatele nazofaringean și orofaringiean. În Indonezia, se folosesc și alte teste pentru a diagnostica boala, cum ar fi testele rapide pentru anticorpii specifici SARS-CoV-2. Prezentăm un caz atipic de COVID-19; am descris modul în care s-a pus diagnosticul, evoluția clinică a pacientului cu progresie spre pneumonie severă în saptămâna 3 și modul în care a fost gestionat cazul. De asemenea am încercat să punem în evidență și posibilele rezultate fals-negative ale reactiei RT-PCR.

Cuvinte-cheie

COVID-19 $\cdot$ SARS-COV2 $\bullet R T-P C R \cdot$ Caz atipic $\cdot$ Seropozitiv

${ }^{*}$ Corresponding author: Andika Chandra Putra

E-mail: andikacppulmo@gmail.com

ว Open Access. ๑ 2020 Suriady et al., published by Sciendo

(c) [BYNC-ND This work is licensed under the Creative Commons Attribution-NonCommercial-NoDerivs 4.0 License. 


\section{Introduction}

In December 2019, the world was notified of a respiratory illness outbreak caused by a novel coronavirus, the acute respiratory syndrome-coronavirus-2 (SARS-CoV-2); this illness was later officially named by the World Health Organization (WHO) as the COronaVIrus Disease-2019 (COVID-19) (1). SARS-CoV-2 is a part of the $\beta$-coronavirus group, which includes viruses causing the severe acute respiratory syndrome and the Middle East respiratory syndrome (1-3), the cause of previous coronavirus outbreaks. This latest coronavirus outbreak originated in Wuhan, a city in the Hubei Province of the People's Republic of China. The outbreak soon spread all around the world and turned into a pandemic of global outreach, with cases numbering in the millions and casualties in the hundreds of thousands (3). The first case of COVID-19 in Indonesia was officially announced by the Indonesian government on 2 March 2020 $(4,5)$. The outbreak most severely hit the capital city, Jakarta, before spreading around the archipelago nation. Based on guidelines from the Indonesia Society of Respirology and the Indonesian Ministry of Health, confirmation of COVID-19 is made using reverse transcriptase-polymerase chain reaction (RT-PCR), but not a rapid antibody test. Herein, we present an atypical case of COVID-19, identified in April 2020 at a private hospital in the capital city of Indonesia, Jakarta.

\section{Case report}

A 69-year-old woman presented to the outpatient clinic, complaining of mild, dry cough and mild shortness of breath since the day before. The patient disclosed that she was a practising dentist who continued to practise during the pandemic without using any personal protective equipment (PPE) during working hours. She denied having any knowledge of contact with suspected or confirmed COVID-19 patients, nor did she acknowledge any travel history to other affected countries. The patient had a history of type 2 diabetes mellitus (T2DM) and hypertension, both of which were well controlled by daily consumption of oral agents. Physical examination showed no discernible abnormality. Laboratory tests were performed and a chest X-ray (CXR) was obtained (Figure 1A). Laboratory results showed a decrease in eosinophil counts and an increase in C-reactive protein (CRP). The CXR showed lung infiltrates in the left perihilar and bilateral laterobasal areas. A diagnosis of pneumonia was made, and the patient was discharged with medication and with instructions in regard to self-isolation.

Five days later, the patient returned to the clinic, presenting with persistent, dry cough and worsening shortness of breath. Physical evaluation showed laborious breathing, with an increased respiratory rate $(R R)$ of 36 times per minute $(x /$ $\min )$, with bilateral rhonchi on pulmonary auscultation. Oxygen saturation $\left(\mathrm{SaO}_{2}\right)$ was measured and found to be $83 \%$ without oxygen supplementation. A CXR examination was ordered (Figure 1B), which showed bilateral paracardiac infiltrates, suggestive of pneumonia. Laboratory examinations showed an increase in neutrophil counts and CRP, as well as a decrease in eosinophil and lymphocyte counts, accompanied by decreased estimated glomerular filtration rate (eGFR) and abnormalities in liver enzymes, lactate dehydrogenase (LDH), and ferritin levels. Taking into consideration the ongoing pandemic, a presumptive diagnosis of COVID-19 pneumonia was made. The patient was subsequently admitted to the hospital.

After admission, the patient was given oxygen supplementation with a non-rebreathing mask (NRM) at 12-15 litres per minute ( $\mathrm{L} / \mathrm{min}$ ), with a corresponding increase in $\mathrm{SaO}_{2}$ to $95 \%-98 \%$ and a decrease in the RR to $20-24 \times / \mathrm{min}$. An empiric antibiotic regiment was given, consisting of azithromycin $(500 \mathrm{mg}$ quaque die [qd] per os [po], i.e. orally every day, for 7 days) and levofloxacin (750 mg qd intravenously [iv] for 10 days). Nasopharyngeal (NP) and oropharyngeal (OP) swabs were then collected to confirm the presumption; the samples were sent to one of Indonesian government's laboratories for reverse transcription-polymerase chain reaction (RT-PCR) testing. By Day 3 of hospitalisation, chloroquine $(150 \mathrm{mg}$ twice daily [bid] po for 10 days) and oseltamivir ( $75 \mathrm{mg}$ bid po for 10 days) were added to the treatment regimen.

On the fourth day of hospitalisation, the patient showed clinical improvement, with a decrease in breathing effort (RR 20-22×/min, $\mathrm{SaO}_{2} 94 \%$ on NRM $10 \mathrm{~L} / \mathrm{min}$ ). But, 2 days later, the patient presented clinical deterioration (RR 26-28 $/ \mathrm{min}$, $\mathrm{SaO}_{2} 90 \%$ on NRM $15 \mathrm{~L} / \mathrm{min}$ ) and was put on high-flow nasal cannula (HFNC) oxygen therapy with $\sim 90 \%$ oxygen fraction. Blood gas analysis was then ordered, with the result showing type 1 respiratory failure with compensated respiratory alkalosis. A second sample of NP swab was taken on the seventh day in the isolation ward, before the result of the first sample was announced by the government. It was processed in the same laboratory as the first NP and OP swabs. Due to a backlog in sample testing, the result of the first NP and OP swabs came out only on Day 8 of hospitalisation; both tested negative for SARS-CoV-2 by RT-PCR.

On the ninth day of hospitalisation, we ordered another CXR (Figure 1C), which showed a progression of the lung infiltrates both in the perihilar and paracardiac areas. On the following day of hospitalisation, the patient's condition had not improved. The antibiotic regimen consisting of azithromycin and levofloxacin had run its course, and thus the patient was given meropenem ( $1 \mathrm{~g}$ three times a day [tid] iv). Methylprednisolone (125 mg tid iv) was also administered, 
which caused a spike in the patient's blood glucose levels. Oral anti-hyperglycemic agents were then replaced with basal and prandial insulin injections.

The patient's vital signs improved on the 12th day from admission, and we could downgrade from HFNC to the previously used NRM, providing an oxygen debit of (15 L/ min). The patient's breathing difficulties were lessened, with $\mathrm{RR}$ of $20 \times / \mathrm{min}$ and $\mathrm{SaO}_{2}$ of $97 \%$. Chloroquine and oseltamivir were stopped after the recommended treatment period ended. Subsequently, methylprednisolone administration was stopped, and the oxygen debit was reduced to $10 \mathrm{~L} /$ min. On the following day, the patient's condition improved significantly, we could replace the NRM with a nasal cannula and lower the oxygen flow up to $3 \mathrm{~L} / \mathrm{min}$. The desired $\mathrm{SaO}_{2}$ of $98 \%$ was reached, with the patient presenting an $\mathrm{RR}$ of $18-20 \times / m i n$. Moreover, the radiological images improved with a decrease in the perihilar and paracardiac infiltrates (Figure 1D).

On the 17th day of hospitalisation, the result of the second NP swab became available, the SARS-CoV-2 RT-PCR on the NP sample proved negative. The patient still reported a slight discomfort in breathing, and thus, we ordered another

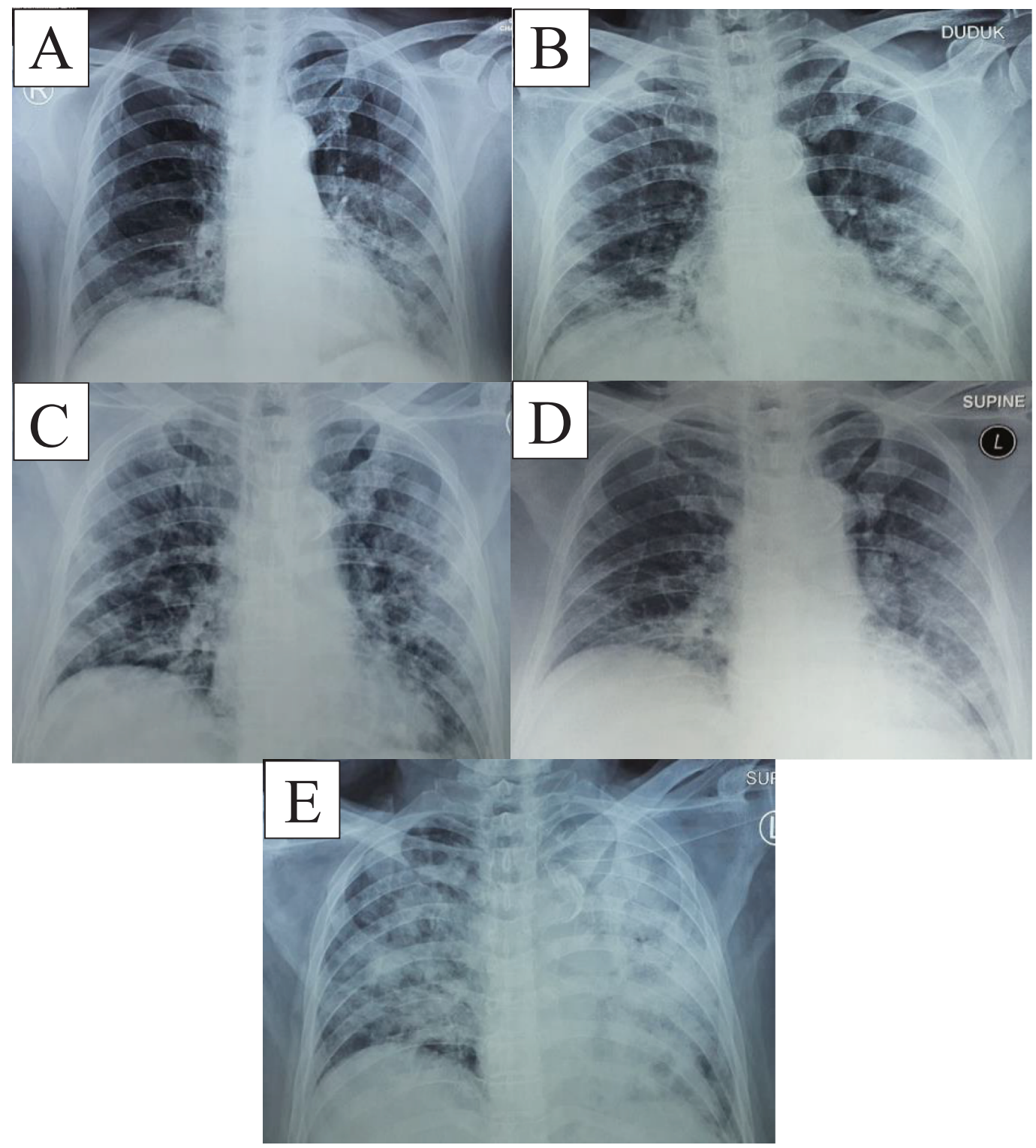

Figure 1. A-E, consecutively: chest X-ray progression and follow-up image on first visit to outpatient clinic, Day 1, Day 9, Day 16 and Day 23 of hospitalisation. 


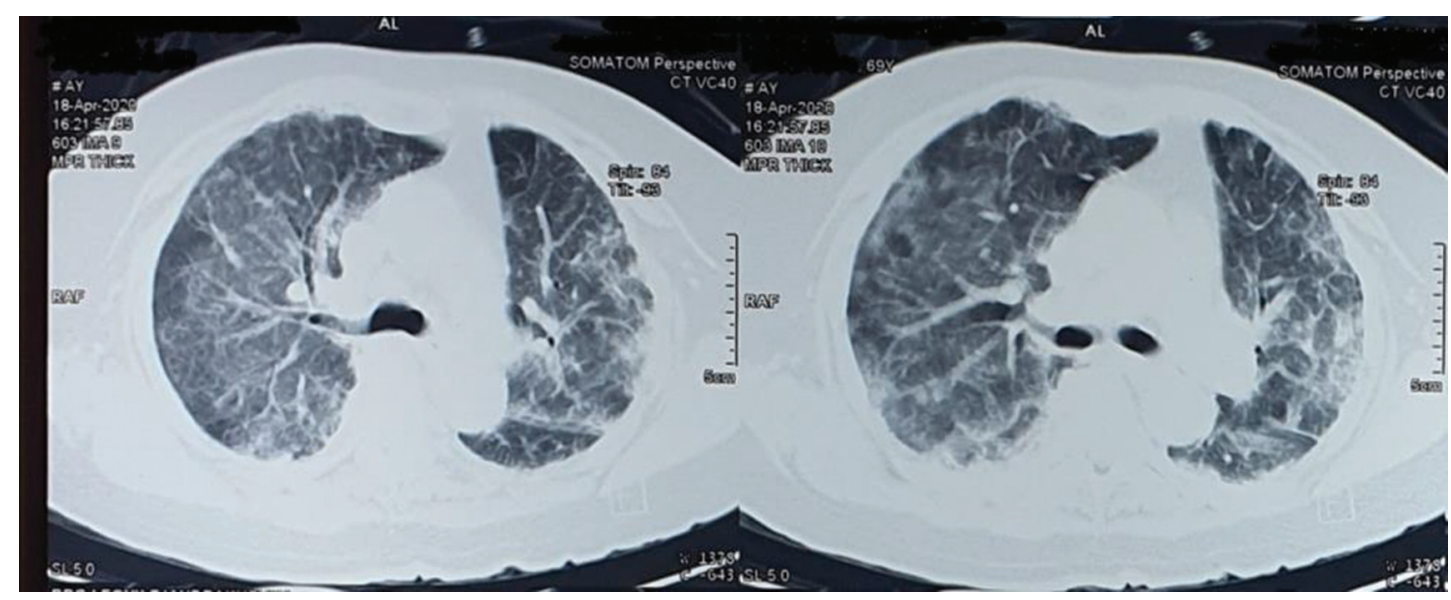

Figure 2. CT scan of chest, taken on the 17th day of hospitalisation.

battery of tests - computed tomography (CT) (Figure 2) scan of the chest, complete blood count (CBC) and serum levels of procalcitonin and CRP. The chest CT scan showed ground-glass opacities in both lungs, suggestive of bilateral pneumonia, which in conjunction with an increase in leucocyte, neutrophil, and CRP levels suggested a secondary bacterial infection.

By the 19th day of hospitalisation, the patient's symptoms had not subsided, and a rapid COVID-19 antibody test was ordered. Both immunoglobulin M (IgM) and immunoglobulin $\mathrm{G}(\mathrm{IgG})$ antibodies were detected in the patient's blood, thus establishing a recent COVID-19 infection. We repeated the NP and OP swabs on the 20th day of hospitalisation, and the samples were sent to a different facility, one able to perform rapid testing. By the next day, the result had been obtained, the samples proved once again negative for SARS-CoV-2. Meropenem administration was discontinued by Day 21 .

The patient had a sudden deterioration in her condition on the 22nd day of hospitalisation. She complained of increasing breathlessness (RR 32×/min, $\mathrm{SaO}_{2} 94 \%$ ), which was accompanied by persistent high fever. The patient was given oxygen via NRM at $10 \mathrm{~L} / \mathrm{min}$. We checked the CBC and CRP levels again and ordered a urinalysis, as well as blood and sputum cultures. The results showed a decrease in haemoglobin and an increase in leucocyte and CRP levels, compared to previous results, with urinary tract infection. There were no follow-up cultures of urine samples, and no sputum was ever collected from the patient. In consequence, moxifloxacin (400 mg qd iv) was then administered.

The patient continued to deteriorate, and by the next day (23rd day), the patient was cyanotic, with signs of impending respiratory failure ( $\mathrm{RR} 32 \times / \mathrm{min}, \mathrm{SaO}_{2} 86 \%$ ), and therefore, the patient was intubated and put on mechanic ventilation. The patient was given azithromycin (500 mg qd po) and tigecycline (loading dose of $100 \mathrm{mg}$ iv, then $50 \mathrm{mg}$ bid iv) as a broad- spectrum treatment for both lung and urinary tract infections. We repeated the CXR (Figure 1E) and blood gas analysis, with results showing a progression of the pulmonary infiltrates in both lungs, predominantly in the left lung; accompanied by type 1 respiratory failure, with uncompensated metabolic acidosis. A series of laboratory examinations were also ordered, which showed a slight increase in the prothrombin time (PT), as well as spikes in procalcitonin and D-dimer, all indicative of sepsis and disseminated intravascular coagulation. On the 24th day of hospitalisation, the initial result from the blood culture sample taken on the 22nd day showed yeast cells, and the patient was administered fluconazole (200 mg qd iv). At this moment, the laboratory tests showed a worsening anaemia and leucocytosis, with an increased activated partial thrombin time (aPTT). A transfusion of $500 \mathrm{cc}$ of packed red cells (PRCs) was then administered. The patient presented a worsening type 1 respiratory failure, with mixed metabolic acidosis and respiratory alkalosis. Moxifloxacin was then substituted with imipenem ( $1 \mathrm{~g}$ four times a day [qid] iv for the first day and then $1 \mathrm{~g}$ tid iv).

On the 25th day of hospitalisation, the rapid antibody test for SARS-CoV-2 was repeated; it showed a positive result for both IgM and IgG. The patient was, by that point, due to septic shock, administered inotropic and vasoconstricting agents. Later that day, the patient went into cardiac arrest. Due to a signed do-not-resuscitate form, the patient did not receive cardiopulmonary resuscitation and was pronounced dead soon after.

\section{Discussion}

We report a case of progressively worsening bilateral pneumonia identified at a private hospital in Jakarta, Indonesia. Concurrent with reports of COVID-19 infections elsewhere, 
the predominant symptoms in this patient were cough and shortness of breath. The patient was a practising dentist, which meant that she was part of a group with a very high risk of acquiring infection in the first place. She also did not use any PPE in her working hours, increasing the probability of getting infected. The patient also had pre-existing conditions: two of which (hypertension and T2DM) were well controlled by oral agents, and a previously unknown early-stage chronic kidney disease (stage 3a). We kept a chart containing the evolution of the patient's symptoms and also her test results (Table 1) to better understand the case.

The symptoms first occurred 6 days before admission to the hospital. Given the disease's incubation period of approximately 5.1 days (6), and lack of any travel history to other affected countries, it is highly probable that the patient acquired the infection from any of her patients during her working hours, highlighting the need for PPE in high-risk groups.

The patient's initial clinical presentation, which predominantly showed a respiratory tract infection, progressed into sepsis and respiratory failure, along with urinary tract infection. The authors noted that there were never any follow-up cultures of urine samples, with the broad-spectrum antibiotic regimen consisting of azithromycin and tigecycline, which were chosen empirically. Tigecycline, although limited in its renal excretion, has shown some efficacy in treating urinary tract infection $(7,8)$. Blood culture results would later show a concurrent fungal infection, which was then treated empirically with fluconazole.

The main confounding part of diagnosis in this patient was the consistently negative RT-PCR result for both NP and OP swab samples. There were three samplings, each on the 7th (NP and OP), the 12th (NP only) and the 22nd (NP and OP) days after the onset of symptoms. The first two were processed at the same facility, while the last sampling was processed in another facility. A study in Hong Kong found that the viral load of SARS-CoV-2 peaked at around onset of symptoms (9), which a study conducted in Guangzhou, China confirmed, stating that throat swabs show high viral load soon after symptoms' onset, gradually decreasing towards detection limit at the 21st day after onset (10). The first sample was taken very late into the progression of disease due to the initial clinical condition of the patient being deemed satisfactory during the first visit to the outpatient clinic. By then, the number of RTPCR facilities capable of detecting SARS-CoV-2 in Indonesia was still very limited, so precedence for the tests of inpatients in serious or critical conditions was a priority. Only the third sampling was done outside of the timeline established by the aforementioned study. Two studies $(11,12)$ conducted in Chongqing and Wuhan, China, both found that the viral load of SARS-CoV-2 from sputum can still be found even after the 21 st day after onset in a majority of cases in which there was undetectable viral load in NP swabs. In this patient's case, there was never any sputum sample taken as a means of diagnosing COVID-19.

The patient's consistently negative results for SARSCoV-2 using RT-PCR of NP swabs were contradictory to her symptoms and radiographic findings, which were characteristic for a viral pneumonia. The next step was testing for antibodies to confirm the suspected diagnosis. The seropositive result for both IgM and IgG for SARS-CoV-2 made clear that the patient recently had COVID-19 infection. The tests were repeated, and similar results were obtained. A study conducted in Shenzhen, China, showed that the median seroconversion time of anti-SARS-CoV-2 IgM is on Day 12 after onset of symptoms (13), while its IgG counterpart is detectable on Day 14. The data is inconsistent with a study conducted in Wuhan, China, which showed that the median seroconversion time of anti-SARS-CoV-2 IgM is on Day 5 after onset of symptoms (14). Such discrepancies could be attributed to the short period of time that has elapsed since the beginning of the SARS-CoV-2 pandemic and the inability to develop complex studies. In regard to this case, antibody testing was conducted on the 19th day of hospitalisation, approximately 25 days after the onset of symptoms. We did not conduct specific quantitative antibody detection due to limited resources.

By WHO definition, routine confirmation of COVID-19 cases involves the detection of the unique sequences of the virus's ribonucleic acid (RNA) using nucleic acid amplification tests (NAAT), such as real-time reverse transcription-polymerase chain reaction (RRT-PCR) and, when necessary, nucleic acid sequencing for confirmation (15). By adhering to this rule, this case could not be confirmed as a definitive COVID-19 case, although the patient's symptoms, signs, laboratory and imaging results, and most importantly, the presence of both IgM and IgG to SARS-CoV-2, all point to COVID-19.

There are a few studies that could attest to our case. A study in China, albeit in a limited sample of just 36 cases, found that the CT scan of the chest has a higher sensitivity (97.2\%) than RRT-PCR (83.3\%) at initial presentation of COVID-19 pneumonia, although all samples tested positive by RRTPCR by the third round of testing (16). A bigger study, also conducted in China, found that among 610 patients clinically diagnosed with COVID-19, 384 (63\%) had an initial negative result on RRT-PCR, which when repeated still resulted in 280 (72.9\% of 384 re-tested) showing negative results (17). This showed that RRT-PCR has limited capability in diagnosing COVID-19, and a more thorough clinical approach should be considered in treating patients with suspected COVID-19. A series of negative RRT-PCR results should not preclude the diagnosis of COVID-19, as the disease is highly contagious, and a misdiagnosed patient could easily spread the disease even further. 


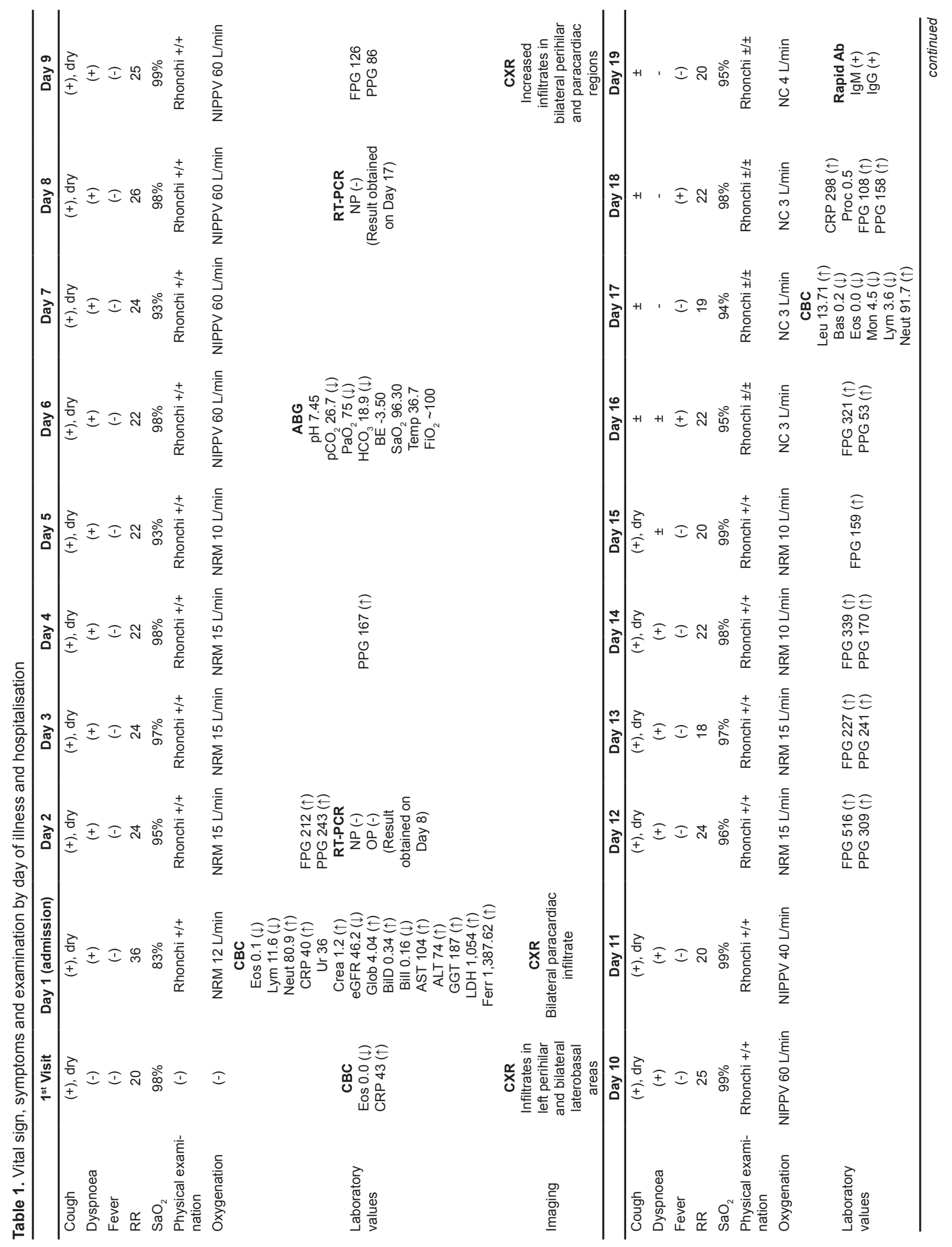




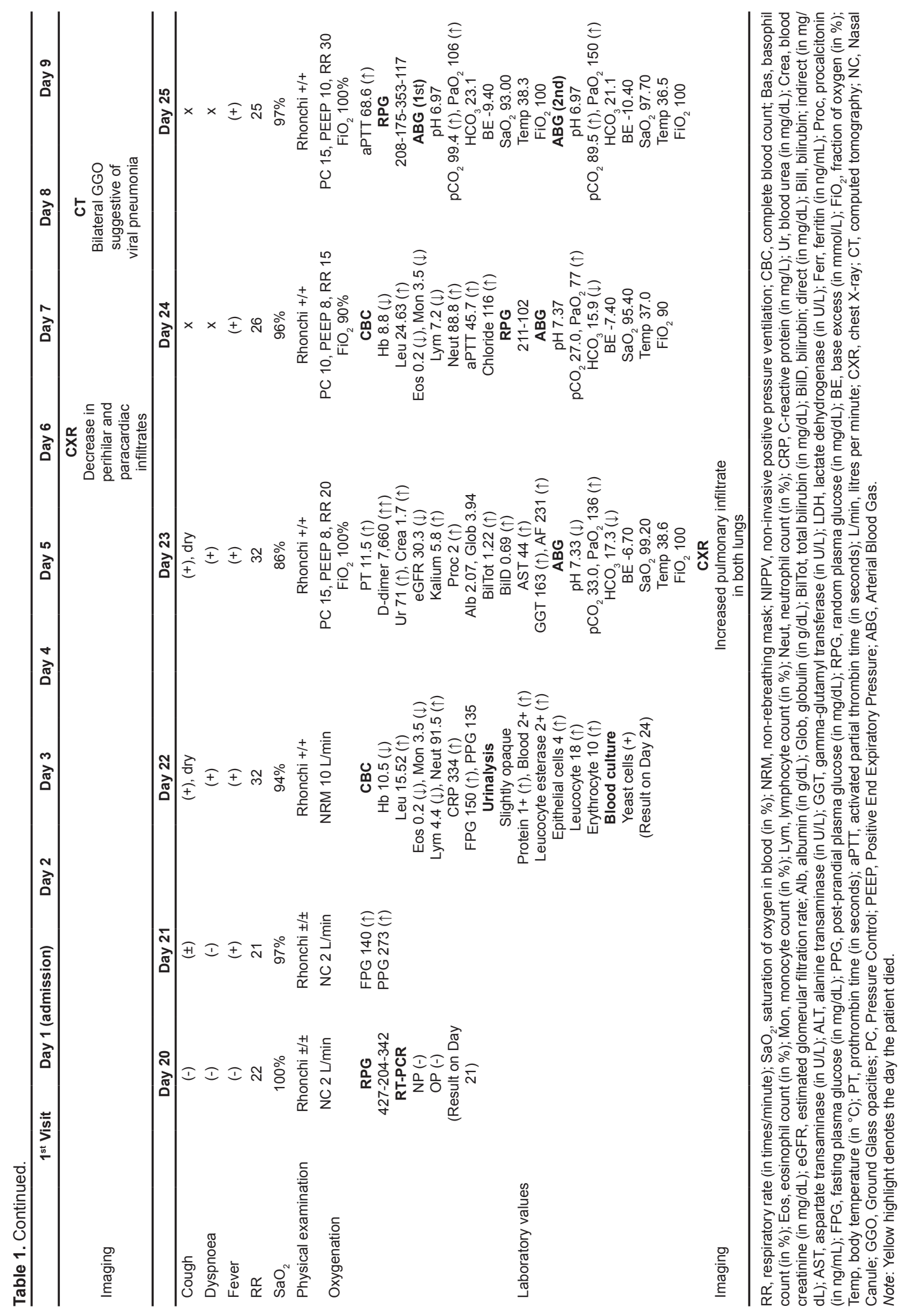




\section{Conclusion}

Our case showed an atypical, presumed case of COVID-19, in which confirmation could not be made following the $\mathrm{WHO}$ definition. This case showed that there may be a need for a more inclusive set of criteria for the diagnosis of COVID-19, because using the current set of criteria leads to under-diagnosis of the disease, especially in a resource-limited setting. Identification of more COVID-19 cases could be vital in the on-going global effort to stem the tide of the deadly pandemic.

\section{Acknowledgement}

The authors thank God who gives us knowledge and skills to treat patients. We also thank all patients and families suffering from COVID-19 in St. Carolus Hospital who helped us with data. We would also like to thank all staff and nurses in St. Carolus Hospital, Jakarta, Indonesia, who are still caring for COVID-19 patients.

\section{Ethical approval}

The authors declare that they have no competing interests and receive patient consent.

\section{Competing interests}

The authors declare that they have no competing interests.

\section{Funding}

This work was personally funded without any grant.

\section{References}

1. Ksiazek TG, Erdman D, Goldsmith CS, Zaki SR, Peret T, Emery $\mathrm{S}$, et al. A novel coronavirus associated with severe acute respiratory syndrome. The New England Journal of Medicine. 2003;348(20): 1953-1966.

2. Zaki AM, van Boheemen S, Bestebroer TM, Osterhaus ADME, Fouchier RAM. Isolation of a novel coronavirus from a man with pneumonia in Saudi Arabia. The New England Journal of Medicine. 2012;367(19): 1814-1820.

3. Chen ZL, Zhang Q, Lu Y, GUO Z-M, Zhang X, Zhang W-J, et al. Distribution of the COVID-19 epidemic and correlation with population emigration from Wuhan, China. Chinese Medical Journal (Engl). 2020;133(9): 1044-1050.

4. First coronavirus cases confirmed in Indonesia amid fears nation is ill-prepared for outbreak 2020 [cited 2020 May, 2]. Available from: http://www.theguardian.com/world/2020/mar/02/first-coronavirus-cases-confirmed-in-indonesia-amid-fears-nation-is-illprepared-for-outbreak.

5. Felix Firyanto W, Windu Cahyaningrum Handayani NotonagoroS. Visit to Singapore Medical Journal during COVID-19 outbreak: learning "beyond" the expectation. Medical Journal of Indonesia. 2020;29: 1

6. Lauer SA, Grantz KH, Bi Q, Jones FK, Zheng Q, Meredith HT, et al. The incubation period of coronavirus disease 2019 (COVID-19) from publicly reported confirmed cases: estimation and application. Annals of Internal Medicine. 2020;172(9): 577-582.

7. Brust K, Evans A, Plemmons R. Tigecycline in treatment of multidrug-resistant Gram-negative bacillus urinary tract infections: a systematic review. Journal of Antimicrobial Chemotherapy. 2014;69(10): 2606-2610.

8. Curcio D. Treatment of recurrent urosepsis with tigecycline: a pharmacological perspective. Journal of Clinical Microbiology. 2008;46(5): 1892-1893.

9. To KK, Tsang OT, Leung W-S, Tam AR, Wu T-C, Lung DC, et al. Temporal profiles of viral load in posterior oropharyngeal saliva samples and serum antibody responses during infection by SARS-CoV-2: an observational cohort study. The Lancet Infectious Diseases. 2020;20(5): 565-574.

10. He X, Lau EHY, Wu P, Deng X, Wang J, Hao X, et al. Temporal dynamics in viral shedding and transmissibility of COVID-19. Nature Medicine. 2020;26: 672-675.

11. Lin C, Xiang J, Yan M, Li H, Huang S, Shen C. Comparison of throat swabs and sputum specimens for viral nucleic acid detection in 52 cases of novel coronavirus (SARS-Cov-2)-infected pneumonia (COVID-19). Clinical Chemistry and Laboratory Medicine. 2020;58(7): 1089-1094.

12. Tan W, Lu Y, Zhang J, Wang J, Dan Y, Tan Z, et al. Viral kinetics and antibody responses in patients with COVID-19. medRxiv. 2020:2020.03.24.20042382.

13. Zhao J, Yuan Q, Wang H, Liu W, Liao X, Su Y, et al. Antibody responses to SARS-CoV-2 in patients of novel coronavirus disease 2019. Clinical Infectious Diseases. 2020;ciaa344. Available from: doi:10.1093/cid/ciaa344.

14. Guo L, Ren L, Yang S, Xiao M, Chang D, Yang F, et al. Profiling early humoral response to diagnose novel coronavirus disease (COVID-19). Clinical Infectious Diseases. 2020;71(5): 778-785.

15. World Health Organization. Laboratory testing for coronavirus disease 2019 (COVID-19)" in suspected human cases: interim guidance, 2 March 2020. Geneva: World Health Organization; 2020: 2020. Contract No.: WHO/COVID-19/laboratory/2020.4.

16. Long $\mathrm{C}, \mathrm{Xu} \mathrm{H}$, Shen $\mathrm{Q}$, Zhang $\mathrm{X}$, Fan B, Wang $\mathrm{C}$, et al. Diagnosis of the Coronavirus disease (COVID-19): rRT-PCR or CT? European Journal of Radiology. 2020;126: 108961.

17. Li Y, Yao L, Li J, Chen L, Song Y, Cai Z, et al. Stability issues of RT-PCR testing of SARS-CoV-2 for hospitalized patients clinically diagnosed with COVID-19. Journal of Medical Virology. 2020;92(7): 903-908. 